\title{
LGMD2A gaixotasunaren diagnostiko molekularra
}

\section{Oihane Jaka}

Biodonostia Institutua eta King's College London

oihane.jaka@kcl.ac.uk

DOI: $10.1387 /$ ekaia.14528

Jasoa: 2015-05-22

Onartua: 2015-06-16

Laburpena: 2A motako gerrietako muskulu-distrofia (LGMD2A) CAPN3 geneko mutazioen ondorio den gaixotasun autosomiko azpirakorra da. CAPN3 geneak muskulu eskeletikoan adierazten den kalpaina 3 proteina kodetzen du. Ikerlan honetan, LGMD2A gaixoen diagnostiko molekularra egin da eta MLPA erabili da berrordenatze posibleak identifikatzeko. Teknika horri esker lau delezio mota identifikatu dira. Gure emaitzetan oinarrituz, LGMD2A gaixotasunaren diagnostiko molekularra egiteko algoritmo bat proposatzen dugu.

Hitz gakoak: gerrietako muskulu-distrofiak, kalpaina 3, delezioak.

Abstract: Limb-girdle muscular dystrophy type 2A (LGMD2A) is an autosomal recessive disorder caused by mutations in the CAPN3 gene. This gene encodes a protein expressed in skeletal muscle called calpain 3 . In the present work we performed the molecular diagnosis of LGMD2A patients and we applied MLPA analysis for the detection of genomic rearrangements. This technique was efficient in identifying four different deletions. Based on our results we propose an algorithm for the molecular diagnosis of LGMD2A.

Keywords: limb-girdle muscular dystrophies, calpain 3, deletions.

\section{SARRERA}

Muskulu-distrofiak herentziazko gaixotasun multzo heterogeneoa dira, eta berorien bereizgarri nagusia gihar eskeletikoko muskulu-zuntzen degenerazio progresiboa da [1]. Ezaugarri histopatologiko nagusiak miozuntzexken haustura, ehun endomisialaren zabaltzea eta gantzaren infiltrazioa dakarten degenerazio-erregenerazio zikloak dira. Muskulu-distrofien artean mota nagusiak honakoak dira, besteak beste: Duchenne-ren muskulu-dis- 
trofia edo onberagoa den Becker-en muskulu-distrofia, distrofia fazioeskapulohumerala, distrofia miotonikoa, Emery-Dreyfuss-en muskulu-distrofia eta gerrietako muskulu-distrofiak (LGMD). Azken horiek gerri pelbikoko eta eskapularreko zein enborreko muskuluei erasaten diete, eta elkarren oso antzekoak dira fenotipikoki. 2A motako gerrietako muskulu-distrofia (LGMD2A), kalpainopatia izenez ere ezagutua, herentzia azpirakorra duen gerrietako muskulu-distrofia mota bat da, kalpaina 3 (CAPN3) geneko mutazioek sortua [2]. Gerrietako muskulu-distrofien maiztasuna oso handia ez den arren, Euskal Herriko populazioari dagokionez, esan beharra dago, batetik, Gipuzkoan LGMD kasuen mundu mailako maiztasun handiena deskribatu dela $\left(69 / 10^{6}\right)$, eta, bestetik, Gipuzkoako LGMD kasu horietatik \%79 LGMD2A formari dagozkiela [3].

\subsection{LGMD2A gaixotasunaren diagnostiko molekularra}

Gaixotasun azpirakorra izaki, LGMD2A-ren diagnostiko molekularra gauzatu ahal izateko, identifikatu egin behar dira CAPN3 genean gaixotasunaren erantzule diren bi mutazioak. Azterketa genetikoa SSCP (Single Strand Conformation Polymorphism) edo DHPLC (Denaturing High Performance Liquid Chromatography) tekniken bidez egin izan da urteetan zehar [4,5], baina teknika horiek negatibo faltsuak eman ditzaketenez, gaur egun genearen 24 exoien sekuentziazio zuzena erabiltzen da laborategi gehienetan. Bestalde, CAPN3-ren mRNA odolean ere adierazten denez, alderantzizko transkripzio bidez lortutako cDNA-ren sekuentziazioak diagnostiko genetiko errazagoa egiteko aukera eskaintzen du, cDNA-ren sekuentziazioa eginez, exoi guztiak segidan aztertzeko aukera baitago [6]. Gainera, cDNA-ren sekuentziazioak beste abantaila bat dakar, DNAren sekuentziazioak ematen ez digun informazio gehigarria eman baitiezaguke batzuetan, hala nola, pre-mRNA-ren moztu-itsastea aldatzen duten mutazioen detekzioa zein exoi baten/batzuen delezioen detekzioa [7]. Azkenik, delezio/duplikazioen bilaketarako MLPA (Multiplex ligation dependent probe amplification) teknika ere erabili ohi da, eta CAPN3 genean teknika hori erabiliz delezio batzuk aurkitu ahal izan dira $[7,8]$.

\section{METODOAK}

Ikerlan hau Donostia Ospitaleko etika-batzordeak onartua izan zen eta laginak eman aurretik parte-hartzaile guztiek baimen informatu bat sinatu zuten. Denera 722 kasuri egin zitzaien LGMD2A-ren diagnostiko genetikoa. Odoleko DNA erauzteko salting-out delako metodoa erabili zen [9]. Odoleko RNAren erauzketa miRNeasy Mini Kit (Qiagen) kita eta QIAcube (Qiagen) makina erabiliz egin zen. cDNA sintetizatzeko High Capacity cDNA Reverse Transcription Kit kita erabili zen (Life Technologies). DNA 
LGMD2A gaixotasunaren diagnostiko molekularra

eta cDNA-ren sekuentziazioa sekuentziadore automatiko batean egin zen (3130 modeloa, Life Technologies). DNAren kopia kopuruak neurtzeko MLPA teknika erabili zen CAPN3 genearentzat diseinaturiko zunda espezifikoak erabiliz (Salsa MLPA kit P176 CAPN3, MRC-Holland).

\section{EMAITZAK}

Gure ikerketa-lantaldean 722 kasuri egin zaie LGMD2A-ren diagnostikoa azken bi hamarkadetan. Hasierako kasuak SSCP teknikarekin aztertu ziren, eta aurrerago DNAren eta cDNA-ren sekuentziazioa erabili dira. Horietatik 271 kasutan 2 mutazio topatu ziren CAPN3 genean, eta diagnostikoa bukatutzat eman zen. 35 kasutan mutazio bakarra topatu zen, eta gainontzeko 416 kasuetan ez zen mutaziorik topatu. Azken kasuak beste muskulu-distrofia batzuen azterketara bideratu ziren. Mutazio bakarra aurkitu zitzaien 35 kasuak MLPA bidez aztertu ziren segidan, aurreko teknikekin detektatu ezin izan ziren delezioak egon zitezkeelakoan. Mutazio homozigoto bat zuten bi ahizpa gaixoren kasuan ere MLPA aplikatu zen (ikus aurrerago). Teknika horri esker 4 delezio mota detektatu ziren, eta bost kasutan diagnostikoa bukatutzat eman zen. Jarraian, banan-banan azalduko dira kasu horiek:

\subsection{2-8 exoien delezioa}

1. gaixoaren DNA SSCP bidez aztertu zenean mutazio bakarra topatu zitzaion heterozigosian: p.(Gly567Trp) (13. exoian). Bigarren mutazioa aurkitu nahian, eta mRNA laginik ezean, MLPA bidez aztertu zen delezio posibleak bilatzeko, eta 2-8 arteko exoiek (biak barne) kontrolekiko dosi erdia zutela ikusi zen. Behin delezio bat zuelako susmo argia izanda, mRNA erauzi ahal izateko berriro atera zitzaion odola gaixoari, eta delezioa cDNA bidez konfirmatu zen delezionatutako gunetik at kokatzen ziren hasleak erabiliz, sekuentziak 1. exoitik 9. exoira jauzi egiten baitzuen.

\subsection{5-7 exoien delezioa}

2. gaixoaren kasuan, laborategira iritsi zen lagin biologikoa DNA izan zenez, sekuentziazioz aztertu zen berori. Teknika horren bidez mutazio bakarra detektatu zen 1. exoian: p.(Pro22Glnfs*35). Diagnostikoaren azterketarekin jarraitu ahal izateko, gaixoari odola atera zitzaion berriro mRNA erauzteko. Baina cDNA sekuentziatu arren, ez zen aipatutako mutazioaz gain besterik aurkitu. Azkenik, delezio bat izan zezakeelakoan MLPA egin zen, eta 5., 6. eta 7. exoiek dosi erdia zutela ikusi zen (1. irudia, A). Aurrez esan bezala, MLPAren aurretik egindako cDNA bidezko sekuentziazioan ez zen delezio hori detektatu. Izan ere, cDNA anplifikatzeko erabiltzen di- 
A) Delezioa heterozigosian

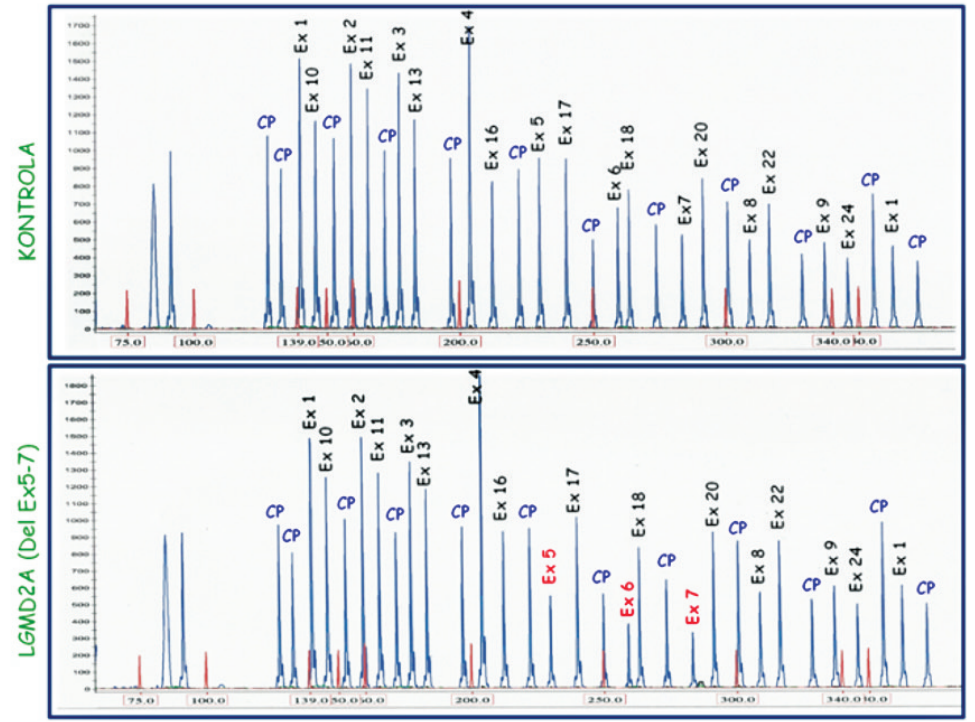

B) Delezioa homozigosian
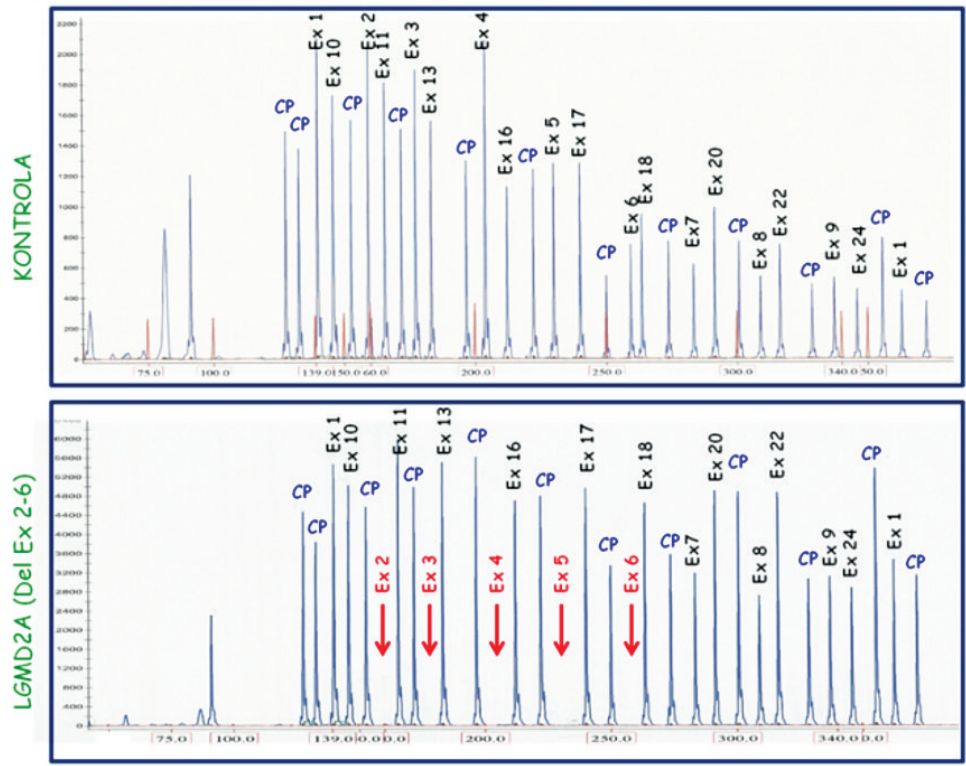

1. irudia. Delezio heterozigoto eta homozigoto baten MLPA profilak. A, 2. gaixoaren kasua: 5., 6. eta 7. exoien delezioa du heterozigosian (kontrolarekiko dosi erdia, gorriz). B, 3. gaixoaren kasua: 2., 3., 4., 5. eta 6. exoien delezioa du homozigosian (anplifikaziorik ez exoi horientzat, gorriz). CP (Control Probe): hainbat kromosomatako kontrol-zundak. Del: delezioa. Ex: exoiak. 
tugun ohiko hasleak delezionatutako eremuan lotzen ziren, eta, beraz, deleziodun aleloak kodetutako cDNA ez zen anplifikatzen gune horretan. Horregatik, sekuentziazioz 1. exoian mutazioa zuen aleloa soilik ikusten zen eremu horren kasuan, zeinak 5., 6. eta 7. exoietan ez duen alteraziorik agertzen. Hasle horiek nahita daude 6. exoian lotzeko diseinatuta, odolean exoi hori ez duten isoformak existitzen direlako, eta, beraz, exoi hori daraman isoforma soilik detektatzeko pentsatuta baitaude. Ondorioz, MLPA teknika erabakigarria izan zen delezio horren detekziorako. Behin gaixoak 5., 6. eta 7. exoien delezioa zuela jakinik, delezionatutako eremutik kanpo lotzen ziren hasleak erabili ziren cDNA sekuentziatu eta delezioa konfirmatzeko.

\subsection{2-6 exoien delezioa}

3. gaixoaren kasuan, DNAren sekuentziazio bidez ez zen mutaziorik detektatu, baina, hainbat aldiz errepikatu arren, zenbait exoiren anplifikazioa ez zen lortzen, eta, beraz, exoi horiek ezin ziren sekuentziatu. Horregatik, delezio bat izan zezakeelakoan, MLPA egin zen. Teknika horri esker gaixoak 2. exoitik 6. exoirainoko delezio homozigoto bat zuela ikusi zen (1. irudia, B). Ondoren, mRNA erauzi ahal izateko berriro atera zitzaion odola gaixoari, eta hasle espezifikoak erabiliz cDNA sekuentziatu zen. Hala, sekuentziak 1. exoitik zuzenean 7. exoira jauzi egiten zuela ikusi zen.

\subsection{Gene osoaren delezioa}

Azkenik, familia bateko bi ahizpa gaixoren DNA sekuentziatzean mutazio bat eta bi polimorfismo topatu ziren homozigosian. Gurasoen DNA aztertzean, baina, amak soilik zituen mutazioa eta bi polimorfismoak (heterozigosian), eta, beraz, alaba gaixoek eta berorien aitak delezio bat izan zezaketela pentsatu genuen. MLPA egin eta bai alabek eta bai aitak CAPN3 gene osoaren delezio heterozigotoa zutela ikusi zen. Genoman hausturapuntua identifikatzeko hainbat teknika aplikatu ondoren, delezioa $C A P N 3$ genearen sekuentzian gora dagoen $G A N C$ genearen 16. introiean hasi eta CAPN3 genearen 3'UTR muturrean amaitzen zela zehaztu zen (72.473 bpren galera) (2. irudia) [10]. Kasu honek agerian utzi zuen sekuentziazioz homozigoto diruditen kasuak ere MLPA bidez aztertzeko beharra, hemizigosi kasuak identifikatu ahal izateko. 


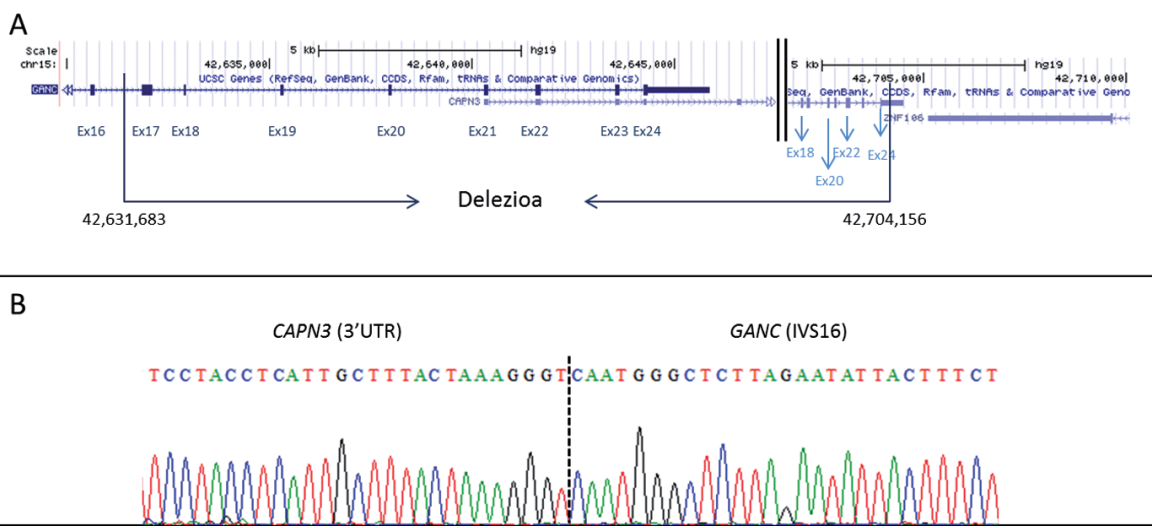

2. irudia. $\quad C A P N 3$ gene osoaren delezioaren sekuentziazioa. A, Delezioaren haustura-puntu genomikoaren kokapena GANC eta CAPN3 geneetan UCSC Genome Browser orriko erreferentzia sekuentzian [11]. B, Delezio genomikoaren sekuentziazioa. Sekuentziak CAPN3 genearen 3'UTR muturretik GANC geneko 16. introira egiten du jauzi (R sekuentzia). Ex: exoia. IVS: introia.

\section{EZTABAIDA}

LGMD2A-ren zein bestelako muskulu-distrofien diagnostiko molekularra ezinbestekoa da aholkularitza genetikorako, ikerketarako, zein etorkizuneko terapien diseinu eta saiakuntza klinikoetarako. Teknologia berrien aplikazioari esker, SSCP/DHPLC gisako teknika ez-zehatzetatik genearen 24 exoien sekuentziazio zuzenera igaro izanak negatibo faltsuen kopurua murrizten lagundu du. Baina DNAren sekuentziazio bidezko diagnostikoa zati kodifikatzaileen anplifikazioan soilik oinarritzen denez oro har, ez ditu detektatzen splice site alternatibo berrien sorrera eragiten duten hainbat mutazio, eta, beraz, teknika horrek ere hainbat negatibo faltsu eman ditzake. 2008an garatutako cDNA-ren sekuentziazioan oinarritutako LGMD2A-ren diagnostikoak horietako batzuen identifikazioan lagundu du [6], baina teknika hori aplikatu arren lan honetako kasu batzuk ezin izan ziren argitu.

Kasu horien ikerketan jarraitzeko, eta aurrez aipatutako teknikekin detektatu ezin izan ziren delezioak egon zitezkeelako susmoa genuenez, MLPA teknika erabili genuen. Horri esker lau delezio mota topatu ditugu. Exoi batzuen delezioa heterozigosian badago, DNAren sekuentziazioz ez dugu delezioa detektatuko, exoi bakoitza bakarka anplifikatu eta sekuentziatzen denez, exoi horien anplifikazioa beste aleloan gertatuko baita soilik, eta, beraz, delezioa ezkutuan geratuko da. Splice site mutazioekin bezala, kasu horretan ere cDNA-ren sekuentziazioak abantaila eskaintzen 
digu. Ondo bidean, exoi batzuen delezioa cDNA-n ikusi beharko litzateke, exoi horiek falta zaizkion RNA trunkatu bat sortuko delako, eta, berori sekuentziatzean, delezioaren berri emango digulako. Baina ikusi dugu hori ez dela beti horrela: 07-497 gaixoaren 5-7 exoien delezioa ez zen cDNA sekuentziatzean ikusi, 6. exoia duen isoforma detektatzeko diseinaturiko hasleak ezin zirelako deleziodun transkrito trunkatuan lotu, eta, beraz, beste mutazioa zuen transkritoa soilik anplifikatzen zuten. MLPA teknika erabili izan ez bagenu, beraz, ez genukeen gaixo horren 2. mutaziorik aurkituko DNA eta cDNA sekuentziatu arren. Horregatik, cDNA-ren sekuentziazioan oinarritutako errutinazko diagnostikoa egin ondoren mutazio bakarra topatu bada, komenigarria da MLPA teknikaren bidez delezio posible baten aukera aztertzea. Berdin DNA sekuentziatuz mutazio bakarra topatu bada, eta RNArik eskuragarri ez badaukagu.

Aipatutako teknikak konbinatu arren, esan beharra dago, DNA edo/eta cDNA sekuentziatu eta MLPA eginda ere, bigarren mutazioa detektatzen ez zaien kasuak egon badaudela. Eta, beraz, LGMD2A-ren diagnostikoak hutsuneak izaten jarraitzen duenez, oraingo erronka nagusia hori guztia aztertu arren mutazio bakarra topatu zaien kasuen bigarren mutazioaren bilaketa nola egin ebaztea da.

\subsection{Diagnostiko molekularra egiteko prozedura-proposamena}

Ikerlan honetan ikusitakoaren arabera, eta, teknika bakoitzaren mugak kontuan hartuta, honako urratsak proposatzen ditugu (3. irudian laburbilduta) LGMD2A-ren diagnostiko molekular egokiena egiteko:

1. Lehenik, RNA laginak eskuragarri izanez gero, cDNA bidezko sekuentziazioa egin beharko litzateke. Ondoren, DNAz baliatuko ginateke, batetik, odoleko RNAtik abiatzen garen kasuetan, 15. exoia ez dagoelako odoleko isoformetan, eta, beraz, exoi hau DNAn sekuentziatu behar delako; eta, bestetik, topatzen diren mutazioen konfirmazioa burutzeko, NMD (Nonsense Mediated Decay) fenomenoaren ondorioz mRNA-ren degradazioa gerta daitekeelako [6].

Mutazio bakarra aurkituko balitz, edota mutazioa homozigosian balego, MLPA egitea komeniko litzateke; batetik, bigarren mutazioa hasleak lotzen diren eremuan kokatzen den delezio bat ote den argitzeko, eta, bestetik, ustezko homozigotoak hemizigosi kasuak diren aztertzeko, hurrenez hurren.

Delezio bat detektatuz gero, delezioaren ingurutik kanpo lotuko liratekeen hasle egokiak aukeratu eta cDNA sekuentziatu beharko litzateke transkrito trunkatua ikusi eta delezioa konfirmatu ahal izateko.

2. Bigarrenik, RNA laginik eskuragarri ez balego, DNA bidezko sekuentziazioa egin beharko litzateke ezinbestean. Kasu horretan ere, DNA- 
ren sekuentziazioan mutazio bakarra topatuko balitz, edota mutazio bat homozigosian ikusiko balitz, MLPA beharrezkoa litzateke delezio posibleak detektatzeko.

Bestalde, DNAren anplifikazioan arazoak baleude ere MLPA egitea komeniko litzateke, delezio homozigoto baten aukera aztertzeko.

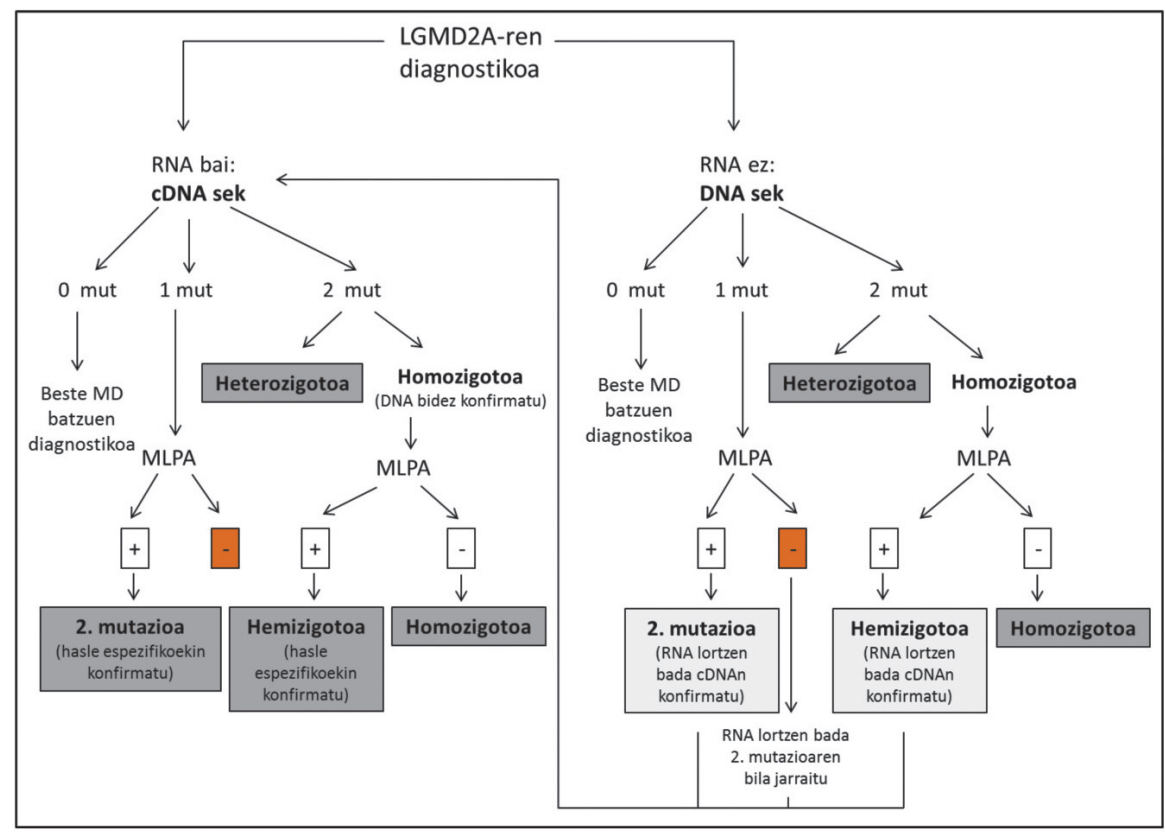

3. irudia. LGMD2A-ren diagnostikoa burutzeko algoritmoa. Gris ilunez markatuta, bi mutazioak topatu direnez bukatutzat emango genituzkeen kasuak. Gris argiz markatuta dauden kasuetan, RNA lagina lortuz gero, delezioa cDNA sekuentziatuz konfirmatzea gomendatzen dugu. DNA eta/edo cDNA sekuentziatu eta MLPA egin ondoren ere mutazio bakarra topatu zaien kasuak (laranjaz) argitu gabeko kasuak lirateke. sek: sekuentziazioa. mut: mutazioa. MD: muskulu-distrofiak. -: MLPA bidez ez da deleziorik detektatu. +: MLPA bidez delezio bat detektatu da.

\section{ESKER ONAK}

Ikerlan hau Eusko Jaurlaritzako Hezkuntza, Unibertsitate eta Ikerketa Sailaren ikertzaileak prestatzeko doktoretza-aurreko beka bati eta Ilundain Fundazioaren ikerketarako laguntzei esker burutu da. 
LGMD2A gaixotasunaren diagnostiko molekularra

\section{BIBLIOGRAFIA}

[1] EMERY, A.E. 2002. «The muscular dystrophies». Lancet, 359, 687-695.

[2] RICHARD, I., BROUX, O., ALLAMAND, V., FOUGEROUSSE, F., CHIANNILKULCHAI, N., BOURG, N., BRENGUIER, L., DEVAUD, C., PASTURAUD, P., ROUDAUT, C., HILLAIRE, D., PASSOS-BUENO, M.R., ZATZ, M. et al. 1995. "Mutations in the proteolytic enzyme calpain 3 cause limb-girdle muscular dystrophy type 2A». Cell, 81, 27-40.

[3] URTASUN, M., SÁENZ, A., ROUDAUT, C., POZA, J.J., URTIZBEREA, J.A., COBO, A.M., RICHARD, I., GARCÍA, B.F., LETURCQ, F., KAPLAN, J.C., MARTI MASSO, J.F., BECKMANN, J.S. eta LÓPEZ DE MUNAIN, A. 1998. «Limb-girdle muscular dystrophy in Guipuzcoa (Basque Country, Spain)». Brain, 121, 1735-1747.

[4] ORITA, M., SUZUKI, Y., SEKIYA, T. eta HAYASHI, K. 1989. «Rapid and sensitive detection of point mutations and DNA polymorphisms using the polymerase chain reaction». Genomics, 5, 874-879.

[5] SÁENZ, A., LeTURCQ, F., COBO, A.M., POZA, J.J., FERRER, X., OTAEGUI, D., CAMANO, P., URTASUN, M., VILCHEZ, J., GUTIÉRREZ-RIVAS, E., EMPARANZA, J., MERLINI, L., PAISAN, C. et al. 2005. «LGMD2A: genotype-phenotype correlations based on a large mutational survey on the calpain 3 gene». Brain, 128, 732-742.

[6] BLÁZQUEZ, L., AZPITARTE, M., SÁENZ, A., GOICOECHEA, M., OTAEGUI, D., FERRER, X., ILLA, I., GUTIÉRREZ-RIVAS, E., VILCHEZ, J.J. eta LÓPEZ DE MUNAIN, A. 2008. «Characterization of novel CAPN3 isoforms in white blood cells: an alternative approach for limb-girdle muscular dystrophy 2A diagnosis». Neurogenetics, 9, 173182.

[7] KRAHN, M., PECHEUX, C., CHAPON, F., BEROUD, C., DROUINGARRAUD, V., LAFORET, P., ROMERO, N.B., PENISSON-BESNIER, I., BERNARD, R., URTIZBEREA, J.A., LETURCQ, F. eta LEVY, N. 2007. «Transcriptional explorations of CAPN3 identify novel splicing mutations, a large-sized genomic deletion and evidence for messenger RNA decay». Clinical Genetics, 72, 582-592.

[8] TODOROVA, A., GEORGIEVA, B., TOURnEV, I., TODOROV, T., BOGDANOVA, N., MITEV, V., MUELLER, C.R., KREMENSKY, I. eta HORST, J. 2007. «A large deletion and novel point mutations in the calpain 3 gene (CAPN3) in Bulgarian LGMD2A patients». Neurogenetics, 8 , 225229.

[9] MILLER, S.A., DYKES, D.D. eta POLESKY, H.F. 1988. «A simple salting out procedure for extracting DNA from human nucleated cells». Nucleic Acids Research, 16, 1215.

[10] JAKA, O., AZPITARTE, M., PAISAN-RUIZ, C., ZULAIKA, M., CASAS, L., SANZ, R., TREVISOL, N., LEVY, N., BARTOLI, M., KRAHN, M., LOPEZ DE MUNAIN, L. eta SÁENZ, A. 2014. «Entire CAPN3 gene dele- 
tion in a patient with limb girdle muscular dystrophy type $2 \mathrm{~A} »$. Muscle and Nerve, 50, 448-53.

[11] KENT, W.J., SUGNET, C.W., FUREY, T.S., ROSKIN, K.M., PRINGLE, T.H., ZAHLER, A.M., HAUSSLER, D. 2002. «The human genome browser at UCSC». Genome Research, 12, 996-1006. 